\title{
Forest Cover Dynamics of a Lowland Rainforest in Southwestern Nigeria Using GIS and Remote Sensing Techniques
}

\author{
Tomiwa V. Oluwajuwon ${ }^{1,2 *}$, Akintunde A. Alo ${ }^{2}$, Friday N. Ogana², Oluwaseun A. Adekugbe ${ }^{3}$ \\ ${ }^{1}$ School of Natural Sciences, Bangor University, Bangor, United Kingdom \\ ${ }^{2}$ Department of Social and Environmental Forestry, University of Ibadan, Ibadan, Nigeria \\ ${ }^{3}$ Department of Forestry and Wood Technology, Federal University of Technology, Akure, Nigeria \\ Email: *tomiwaoluwajuwon@gmail.com
}

How to cite this paper: Oluwajuwon, T.V., Alo, A.A., Ogana, F.N. and Adekugbe, O.A. (2021) Forest Cover Dynamics of a Lowland Rainforest in Southwestern Nigeria Using GIS and Remote Sensing Techniques. Journal of Geographic Information System, 13, 83-97.

https://doi.org/10.4236/jgis.2021.132006

Received: January 27, 2021

Accepted: March 5, 2021

Published: March 8, 2021

Copyright $\odot 2021$ by author(s) and Scientific Research Publishing Inc. This work is licensed under the Creative Commons Attribution International License (CC BY 4.0).

http://creativecommons.org/licenses/by/4.0/

(c) (i) Open Access

\begin{abstract}
The rate of forest degradation and deforestation in Nigeria has been increasing over the years and is prominent in the southwestern parts. Despite the significant change and degradation observed in a lowland rainforest in the region-Ogbese Forest Reserve, there is a great dearth of information about the level of forest cover change. Therefore, this study determined the cover dynamics of the rainforest reserve over the epoch of 20 years using Geographic Information System and remote sensing techniques. Coordinates of the boundary and some other benchmark places within the forest reserve were obtained. Secondary data collection included: Landsat imageries of 1998, 2002 and 2018. An interview guide was used to obtain information from forest officials and locals of the surrounding communities to complement the spatial data obtained. Image classification was done using the maximum likelihood algorithm. The rate of change across the epochs was determined using the area of the land cover classes. The level of vegetation disturbance in the reserve was determined through Normalized Difference Vegetation Index. Five different forest cover classes were identified in the study area: forest, plantation, farmland, grassland, and bare land. The natural forest reduced significantly from $34.43 \mathrm{~km}^{2}$ (48\%) in 1998 to $8.73 \mathrm{~km}^{2}$ (12\%) in 2002 and was depleted further by 2018 , while other cover classes increased. NDVI value also reduced from 0.25 to 0.13 . Agriculture, among others, was observed as the main driver of forest degradation and deforestation in Ogbese Forest Reserve. The study concluded that the remaining forest (i.e. plantation) could also be depleted by 2025 , as it decreases by $-0.94 \mathrm{~km}^{2}$ per year if proper reforestation and management practices are not introduced.
\end{abstract}




\section{Keywords}

Change Detection, Land Use/Land Cover, Normalized Difference Vegetation Index, Deforestation Drivers

\section{Introduction}

Tropical forests have been associated with the highest species richness and diversity amongst other ecosystems but have been overexploited [1]. This is evident in many developing countries including those in Sub-Saharan Africa where the rates of forest degradation and deforestation have been increasing over the years. According to [2], Africa has the highest deforestation rate of $2.8 \%$ with her natural forest declining at a net rate of about $3.2 \%$ within the period 2010-2015. Similarly, there has been significant change and reduction in most of the forest cover in Nigeria. The country has been losing an average of $11 \%$ of its primary forests annually since 2000-doubling the rate of the 1990s, and about 5\% from 2010 to 2015 [2] [3]. Many factors constituting such deforestation have been in recent studies linked to various anthropogenic activities [2] [4] [5]. The conversion of forest reserves to other land-uses has caused many complex changes in the forest ecosystems whose impacts raise diverse ecological problems [6] [7]. The establishment of monoculture plantations and encroachment by landless farmers for agricultural activities have significantly culminated in the degradation of substantial parts of most of the forest reserves in Southwestern Nigeria [4] [8]. Degradation of natural resources, especially land and forest, has become a serious concern in developing countries, where most rural people depend on these natural resources for sustenance [2] [7].

Typically, some of the forest cover in most developing countries has been converted to another cover and subjected to different uses at varying temporal and spatial scales [9] [10], which has resulted into changes in the forest. Such changes may be rapid (e.g. clearing of forest for agriculture) or relatively slow (e.g. tree damage and death due to acid rain) and may affect both socio-economic and ecological conditions [11]. Globally, the detection and monitoring of the extent and patterns of the changes over time have been made easier and more accurately with the use of remote sensing techniques [12] [13]. Mapping of forest cover, as well as their changes, provides invaluable information for managing their resources and for projecting future trends of forest land productivity [14].

Following the trending land cover dynamics studies globally, quite a number of researches have been conducted for forest cover changes in Nigeria. For instance, the land use dynamics of Ikere, Eda and Ago-owu forest reserves, amongst other few, have been delineated to ascertain their levels of deforestation [15] [16] [17]. The land use/land cover change of the southwestern state where Ogbese Forest Reserve is located has been evaluated [18]. However, no research involving the spatial assessment either by conventional tools or remote sensing 
and GIS technologies has so far been particularly conducted on the lowland rainforest reserve. Meanwhile, an old study [19] corroborated by recent observations revealed that the reserve has been largely depleted as a result of the agricultural activities by the dependent communities, and was composed of plantation patches of few species by 2015 [20]. The reserve lacks adequate land cover dynamics database through which its extent and rates of degradation and possible deforestation could be assessed and monitored over time. Therefore, this study aimed at assessing the forest cover dynamics of Ogbese Forest Reserve in Ekiti State, Nigeria over the period of 20 years with a view to project future change and recommend sustainable forest management practices.

\section{Material and Methods}

\subsection{Study Area}

The study was carried out in Ogbese Forest Reserve, Ekiti State in Southwestern Nigeria. The reserve covers an area of $72.52 \mathrm{~km}^{2}$ and lies approximately between Latitudes $7^{\circ} 30^{\prime} \mathrm{N}$ and $7^{\circ} 35^{\prime} \mathrm{N}$ and Longitudes $5^{\circ} 19^{\prime} \mathrm{E}$ and $5^{\circ} 24^{\prime} \mathrm{E}$ (Figure 1). The reserve experiences a tropical climate with distinct wet and dry seasons. The rainy season lasts for 9 months annually between March and November while the dry season lasts for 3 months between December and February. The annual mean total rainfall is $1367 \mathrm{~mm}$; the average number of the rainy days is 112 per

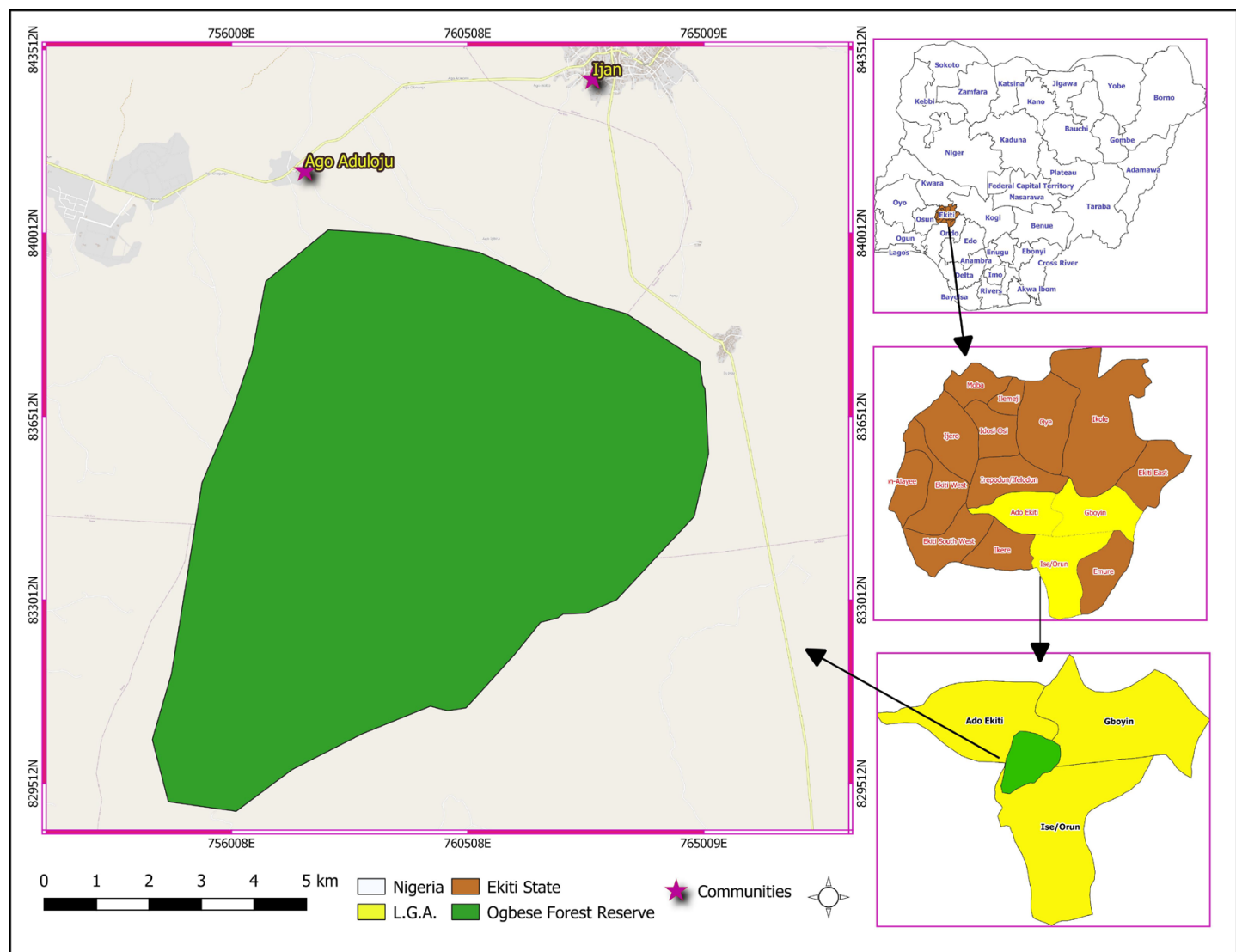

Figure 1. Study area. 
annum. Temperature is almost uniform throughout the year with very little deviation from the mean annual of $27^{\circ} \mathrm{C}$. The mean annual relative humidity varies between $50 \%$ and $95 \%$ and is highest in the rainy season months [21]. It is composed of the plantation of mixtures of tree species such as Terminalia ivorensis A. Chev., Tectona grandis Linn. F. and Gmelina arborea Roxb., established in 1998 by a manual clearing of the former vegetation [20].

\subsection{Method of Data Collection}

The coordinates of the boundary of Ogbese Forest Reserve were obtained from the reserve. Landsat Thematic Mapper (TM), Enhanced Thematic Mapper Plus (ETM+) and Operational Land Imager/Thermal Infrared Sensor (OLI/TIRS) images were also obtained from the official website of United States Geological Survey (USGS) (Table 1). In addition, data were collected on the vegetation cover, land use land cover type and the topography of the study area with the use of Global Positioning System (GPS) in taking coordinates at several locations.

Key informant interview approach involving a structured in-depth interview guide to 10 respondents was used to obtain information from Forest Officials and Communities to complement the spatial data, especially on the drivers of deforestation in the study area. Five (5) Forest Officials including Forest Officers and Uniform Officers were selected using random sampling, considering their years of experience at the Forestry Department and with the reserve. Five (5) people were also randomly chosen from two (closest) surrounding communities Ago-Aduloju and Ijan.

\subsection{Method of Data Analysis}

Since images downloaded were for the whole cover within the path and row (190 and 055), hence masking was done with the use of the rectified shapefile to clip and query the concerned part of the satellite imageries. Subsequent was compositing which allows vegetation to be detected readily in the images. False colour composite (FCC) images of Landsat TM (1998), Landsat ETM+ (2002) and Landsat OLI/TIRS (2018) data were made and processed using ArcMap 10.3 software. A supervised classification algorithm method using the Maximum-Likelihood Classification (MLC) was harnessed to classify the imageries into forest cover classes for better interpretation, where an average number of 20 training samples were collected for each image with over 2000 pixels each. Maps portraying the cover classes across the three epochs were composed. The pixel counts for the

Table 1. Characteristics of the satellite imageries acquired.

\begin{tabular}{ccccc}
\hline Sensor & Date & Path/row & Spatial resolution $(\mathrm{m})$ & Source \\
\hline Landsat TM & 1998 & $190 / 55$ & 30 & USGS \\
Landsat ETM+ & 2002 & $190 / 55$ & 30 & USGS \\
Landsat OLI/TIRS & 2015 & $190 / 55$ & 30 & USGS \\
Landsat OLI/TIRS & 2018 & $190 / 55$ & 30 & USGS
\end{tabular}

USGS (http://www.landsat.usgs.gov/). 
individual cover classes, representing their spatial cover, were used to extrapolate the areas (in square kilometres) of the classes with respect to that of the Forest Reserve. For the change detection, a comparison of land cover statistic method was adopted. The percentage change, trend, and rate of change between each of the epochs were calculated using the areas $\left(\mathrm{km}^{2}\right)$ of the land cover classes. Similar method was used by [22] and [23].

$$
\begin{gathered}
\% \Delta=\frac{\mathrm{OC}}{\mathrm{ASC}} \times 100 \\
\% \Delta / y_{r}=\frac{Y_{2}-Y_{1}}{Y_{1}} \times 100 \\
\text { Average Rate of Change }=\frac{Y_{2}-Y_{1}}{T_{2}-T_{1}} \\
\% \text { Average Rate of Change }=\frac{\text { Average Rate of Change }\left(\mathrm{km}^{2}\right)}{\text { Difference in years }}
\end{gathered}
$$

where $\Delta$ represents change; OC is the observed change; ASC is the absolute sum of change (i.e., fixed or initial year); $Y_{1}$ and $Y_{2}$ are the areas (sizes) at initial year $\left(T_{1}\right)$ and final year $\left(T_{2}\right)$, respectively.

Normalized Difference Vegetation Index (NDVI) was calculated using bands 4 and 5 of Landsat- 8 OLI/TIRS, and bands 3 and 4 in both Landsat- 5 TM and Landsat-7 ETM+ with the aid of spectral indices tool. The formula below was used to compute the NDVI, and its trend, using the imageries obtained for 1998, 2002, 2015 and 2018:

$$
\mathrm{NDVI}=\frac{\mathrm{NIR}-\mathrm{RED}}{\mathrm{NIR}+\mathrm{RED}}
$$

where NDVI is Normalized Difference Vegetation Index; NIR represents Near-Infrared band and RED is the Red band.

The cover of the forest reserve was delineated into classes over the studied epochs [24]. The forest cover description indicated that; evergreen, deciduous and wetland forest vegetation were referred to as forest, land area occupied with (mixture of) trees planted artificially were referred to as plantation, land use for agricultural purposes were referred to as farmland, land area with much less vegetation than plantation were referred to as grassland while land area not under agricultural uses and with no vegetation during the study was referred to as bare land (Table 2).

Table 2. Forest cover classes in Ogbese Forest Reserve and their description.

\begin{tabular}{cr}
\hline Forest Cover Class & Description \\
\hline $\begin{array}{c}\text { Forest } \\
\text { Plantation } \\
\text { Farmland }\end{array}$ & Includes; evergreen, deciduous and wetland (natural) forest vegetation \\
Grassland & The land area occupied with (mixture of) trees planted artificially \\
Bare land & Land use for agricultural purposes \\
The land area with much less vegetation than plantation
\end{tabular}

Adapted from [24]. 
The qualitative data collected from the forest officials and the community members through the interview guide were analyzed using Statistical Package for the Social Sciences (SPSS) 14.0 to support the spatial data. Descriptive statistics was used in the analysis to determine and rank the several drivers of deforestation in the rainforest reserve.

\section{Results}

Five land use land cover were identified in the study area: forest, plantation, farmland, grassland and bare land with a total land area of about $72 \mathrm{~km}^{2}$ (Figures 2-4). In 1998, it was observed that the forestland amounted to almost half of the total area i.e., $48 \%\left(34.43 \mathrm{~km}^{2}\right)$ (Figure 2). The plantation covered an area of about $13 \%\left(9.50 \mathrm{~km}^{2}\right)$ of the total land area in 1998. About $20 \%\left(14.02 \mathrm{~km}^{2}\right)$ of the reserve was covered by farmland as the second-largest cover class. The portion that was covered by grassland and bare land were minimal with percentage cover of about $11 \%\left(8 \mathrm{~km}^{2}\right)$ and $8 \%\left(6.05 \mathrm{~km}^{2}\right)$, respectively. Figure 3 shows that forests were more abundant in the northeastern part of the reserve while grassland dominated the western as farmland was dispersed about the entire cover. The plantation was mostly concentrated at the northwestern area of the reserve.

In 2002 , the percentage land area converted to farmland was $31 \%\left(22.44 \mathrm{~km}^{2}\right)$ (Figure 3). The forest which almost covered half of the reserve was reduced to about $12 \%$ by 2002 (i.e. $8.78 \mathrm{~km}^{2}$ ). In the stead of the forest expansion, plantation forest was largely engaged in as it accounted for $29 \%$ of the forest reserve

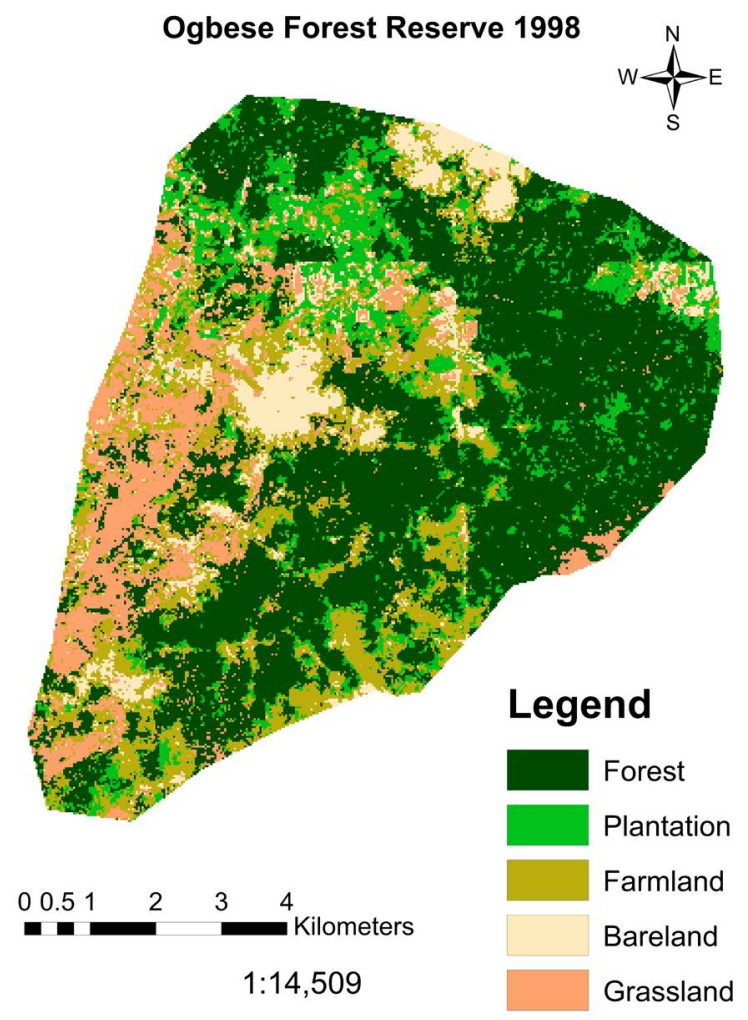

Figure 2. Land use land cover for 1998. 


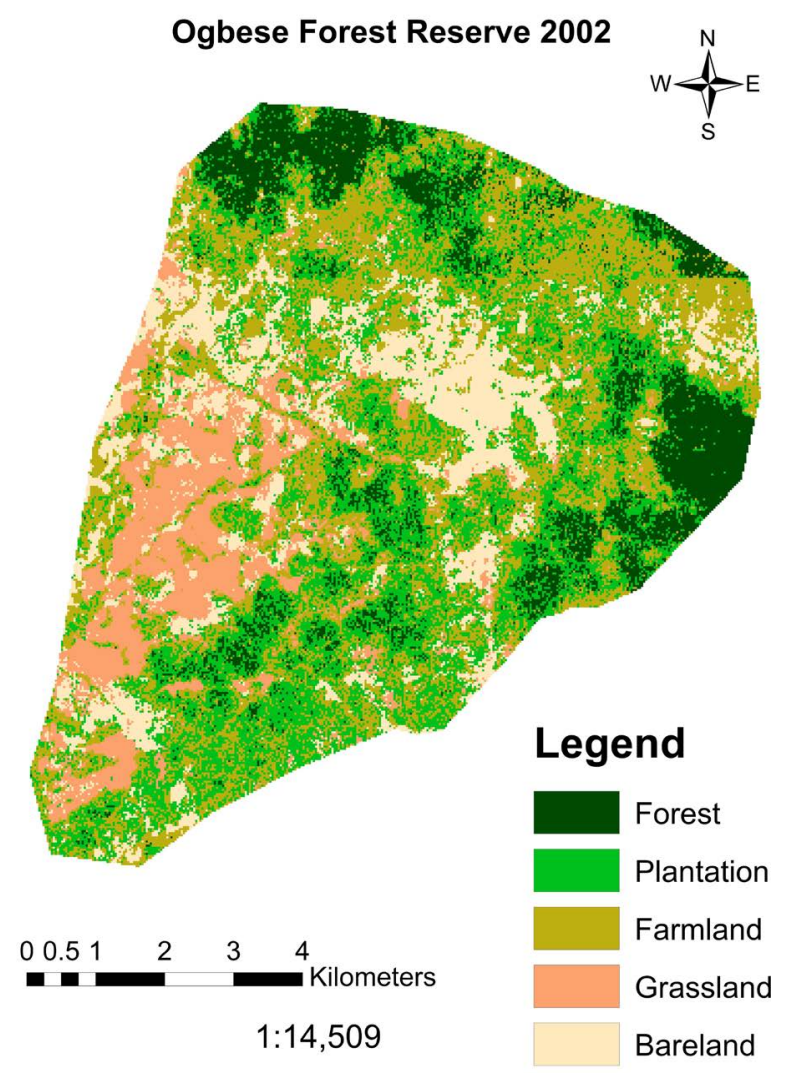

Figure 3. Land use land cover for 2002.

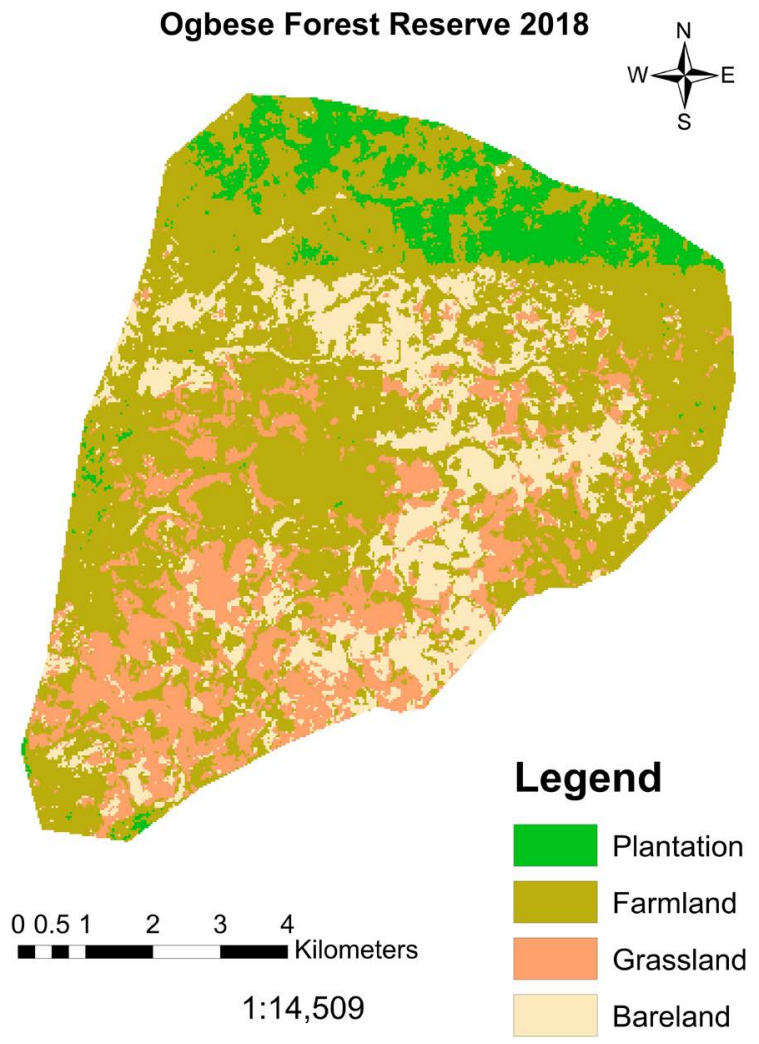

Figure 4. Land use land cover for 2018. 
area. Land under no vegetation also increased to $10.67 \mathrm{~km}^{2}$, while grassland accounted for $13 \%$ of the entire area. Both plantations and farmland, being the most dominant cover classes, were much distributed throughout the reserve, while the grassland still had much cover in its western part.

The result of the recent analysis of the forest cover, in 2018, showed that the natural forest vegetation has been completely depleted. Only a few percentage areas of the entire reserve, i.e. $5.94 \mathrm{~km}^{2}$, are reserved under plantations (Table 3). Agricultural activities have become dominant in the reserve having accounted for $55 \%$ of the reserve. Bare land and grassland both increased in cover in the reserve to $12.85 \mathrm{~km}^{2}$ and $13.50 \mathrm{~km}^{2}$ respectively. The few "green" in the estate are localized in the northern part of the site (Figure 4).

\subsection{Forest Cover Change of Ogbese Forest Reserve}

The forestland as at 1998 covered almost half of the entire reserve (i.e. 34.43 $\mathrm{km}^{2}$ ), accounting for about $48 \%$ has decreased to $8.73 \mathrm{~km}^{2}$ by 2002 (Table 4 ).

Table 3. Areal extent of forest cover of Ogbese Forest Reserve.

\begin{tabular}{ccccccc}
\hline \multirow{2}{*}{ Classification } & \multicolumn{2}{c}{1998} & \multicolumn{2}{c}{2002} & \multicolumn{2}{c}{2018} \\
\cline { 2 - 6 } & Area $\left(\mathrm{km}^{2}\right)$ & $\%$ & Area $\left(\mathrm{km}^{2}\right)$ & $\%$ & Area $\left(\mathrm{km}^{2}\right)$ & $\%$ \\
\hline Forest & 34.43 & 47.82 & 8.73 & 12.12 & 0 & 0 \\
Plantation & 9.50 & 13.19 & 20.91 & 29.04 & 5.94 & 8.26 \\
Farmland & 14.02 & 19.47 & 22.44 & 31.17 & 39.71 & 55.15 \\
Grassland & 8.00 & 11.10 & 9.25 & 12.85 & 13.50 & 18.75 \\
Bare land & 6.05 & 8.41 & 10.67 & 14.82 & 12.85 & 17.84 \\
Total & 72.00 & 100.00 & 72.00 & 100.00 & 72.00 & 100.00 \\
\hline
\end{tabular}

Table 4. Forest cover change and rate of change in Ogbese FR between 1998 and 2018.

\begin{tabular}{|c|c|c|c|c|c|c|c|c|c|c|c|c|c|c|c|}
\hline \multirow[b]{2}{*}{ Classification } & \multirow{2}{*}{$\begin{array}{c}1998 \\
\\
\text { Area } \\
\left(\mathrm{km}^{2}\right)\end{array}$} & \multirow{2}{*}{$\begin{array}{l}2002 \\
\text { Area } \\
\left(\mathrm{km}^{2}\right)\end{array}$} & \multirow{2}{*}{$\begin{array}{c}2018 \\
\text { Area } \\
\left(\mathrm{km}^{2}\right)\end{array}$} & \multicolumn{4}{|c|}{ 2002-1998 } & \multicolumn{4}{|c|}{ 2018-2002 } & \multicolumn{4}{|c|}{ 2018-1998 } \\
\hline & & & & $\begin{array}{c}\text { Change } \\
\text { in Area } \\
\left(\mathrm{km}^{2}\right)\end{array}$ & $\begin{array}{c}\% \\
\text { Change } \\
(\%)\end{array}$ & $\begin{array}{l}\text { Average } \\
\text { rate of } \\
\text { change } \\
\left(\mathrm{km}^{2} / \mathrm{yr}\right)\end{array}$ & Remark & $\begin{array}{c}\text { Change } \\
\text { in Area } \\
\left(\mathrm{km}^{2}\right)\end{array}$ & $\begin{array}{c}\% \\
\text { Change } \\
(\%)\end{array}$ & $\begin{array}{l}\text { Average } \\
\text { rate of } \\
\text { change } \\
\left(\mathrm{km}^{2} / \mathrm{yr}\right)\end{array}$ & Remark & $\begin{array}{c}\text { Change } \\
\text { in Area } \\
\left(\mathrm{km}^{2}\right)\end{array}$ & $\begin{array}{c}\% \\
\text { Change } \\
(\%)\end{array}$ & $\begin{array}{c}\text { Average } \\
\text { rate of } \\
\text { change } \\
\left(\mathrm{km}^{2} / \mathrm{yr}\right)\end{array}$ & Remark \\
\hline Forest & 34.43 & 8.73 & 0 & -25.70 & -74.64 & -6.43 & $-\mathrm{ve}$ & -8.73 & -100.00 & -0.55 & $-\mathrm{ve}$ & -34.43 & -100.00 & -1.72 & $-\mathrm{ve}$ \\
\hline Plantation & 9.50 & 20.91 & 5.94 & 11.41 & 120.11 & 2.85 & +ve & -14.97 & -71.59 & -0.94 & - ve & -3.56 & -37.47 & -0.18 & - ve \\
\hline Farmland & 14.02 & 22.44 & 39.71 & 8.42 & 60.06 & 2.11 & $+\mathrm{ve}$ & 17.27 & 76.96 & 1.08 & +ve & 25.69 & 183.24 & 1.28 & +ve \\
\hline Grassland & 8.00 & 9.25 & 13.50 & 1.25 & 15.63 & 0.31 & +ve & 4.25 & 45.95 & 0.27 & +ve & 5.5 & 68.75 & 0.28 & + ve \\
\hline Bare land & 6.05 & 10.67 & 12.85 & 4.62 & 76.36 & 1.16 & $+\mathrm{ve}$ & 2.18 & 20.43 & 0.14 & + ve & 6.8 & 112.40 & 0.34 & $+\mathrm{ve}$ \\
\hline Total & 72.00 & 72.00 & 72.00 & & & & & & & & & & & & \\
\hline \multicolumn{16}{|l|}{ Summary } \\
\hline Forest & 34.43 & 8.73 & 0 & -25.70 & -74.64 & -6.43 & & -8.73 & -100.00 & -0.55 & & -34.43 & -100.00 & -1.72 & \\
\hline Non-Forest & 37.57 & 63.27 & 72 & 25.70 & 68.41 & 6.43 & & 8.73 & 13.80 & 0.55 & & 34.43 & 91.64 & 1.72 & \\
\hline
\end{tabular}

$\mathrm{N}: \mathrm{B}$-ve means decreased change in area while +ve implies a positive change. 
Plantation increased largely from $9.50 \mathrm{~km}^{2}$ to $20.91 \mathrm{~km}^{2}$, while farmland 14.02 $\mathrm{km}^{2}$ to $22.44 \mathrm{~km}^{2}$ (20\% to $31 \%$ ). The land area covered with no vegetation, which has the lowest area in $1998\left(6.05 \mathrm{~km}^{2}\right)$, expanded by 2002 increasing to $10.67 \mathrm{~km}^{2}$ as a result of some deforestation agents such as poaching and fires. The forested area reduced drastically at a rate of $-6.43 \mathrm{~km}^{2}$ per year, while plantation and farmland increased at rates 2.85 and 2.11 per year respectively.

The rate at which the cover change progressed from 2002 to 2018 showed a drastic decrease and eventual total depletion of the forested area from $8.73 \mathrm{~km}^{2}$ accounting for $12 \%$ of the total land area to nil (Table 4). Likewise, the area under plantation forest reduced largely from $29 \%$ cover to $8 \%$. Within this period, bare land and grassland increased minimally from $15 \%$ to $18 \%$ and $13 \%$ to $19 \%$ of the total land area, respectively. Notably, farmland however increased considerably with percentage increase of almost $80 \%$ from $22.44 \mathrm{~km}^{2}$ to $39.71 \mathrm{~km}^{2}$.

\subsection{Level of Disturbance in Ogbese Forest Reserve}

The NDVI was the index used to determine the level of disturbance in Ogbese forest reserve between 1998 and 2018 considering the years 1998, 2002, 2015 and 2018 data. The level of disturbance based on the NDVI values obtained over the forest reserve revealed that as at 1998 , the value was 0.25 indicating less dense vegetation cover which reduced to 0.22 in 2002 . By 2015, the level of disturbance has been significantly increased, by the advancement of farming in the reserve, with the NDVI reduction to 0.15 which has recently been observed to be 0.13 (Figure 5).

\subsection{Drivers of Deforestation in Ogbese Forest Reserve}

The drivers of deforestation in the reserve over the years have been; excessive timber felling or logging, agriculture, the incidence of fires, livestock grazing, poaching or encroachment, fuelwood collection and charcoal production (Figure 6). It was obtained that the major cause of the total depletion of natural forest

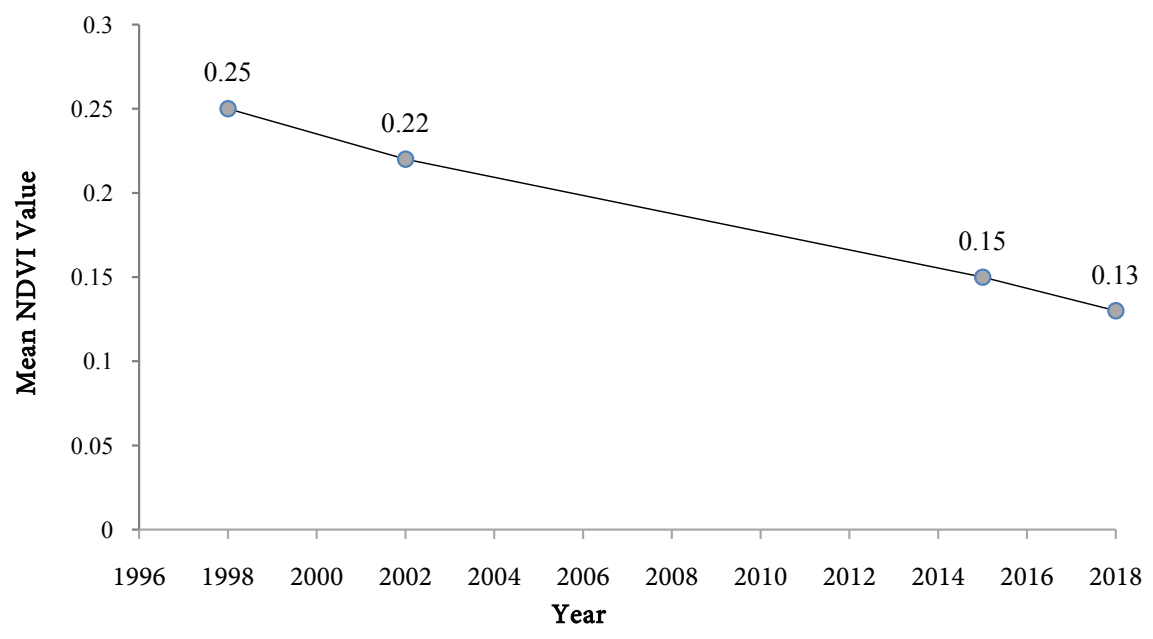

Figure 5. Line graph showing the level of disturbance over the years in the reserve. 


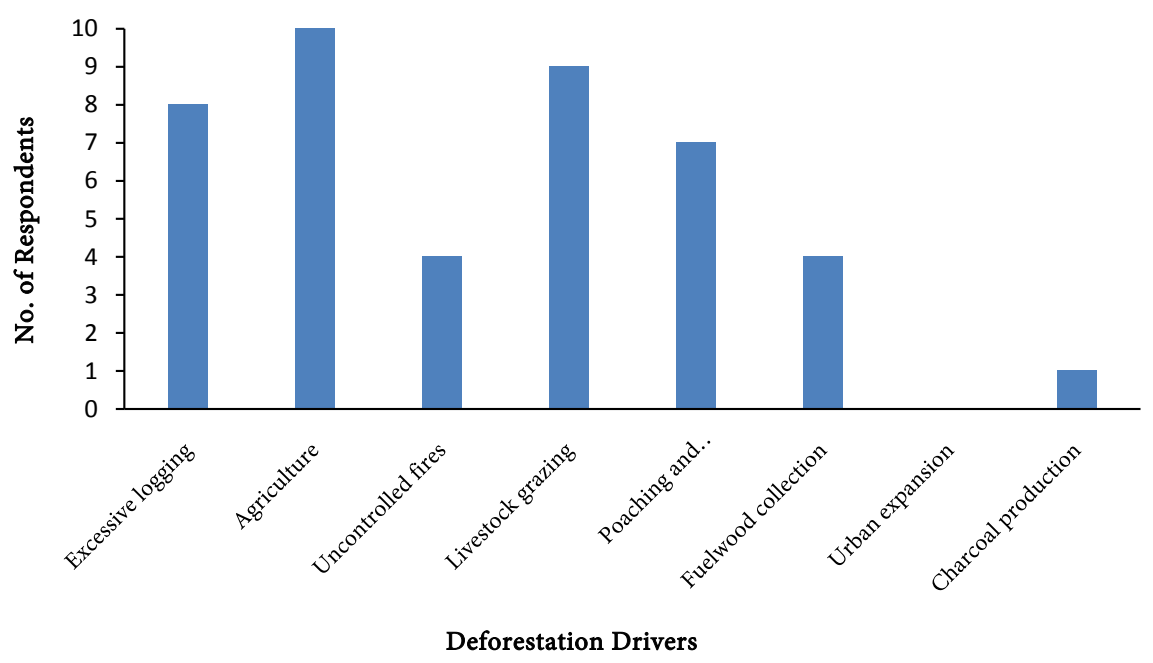

Figure 6. Drivers of deforestation in the study area.

and consistent removal of plantation forest in the reserve has been the conversion of most of its cover to farmland, i.e. agriculture. About $60 \%$ of the reserve cover has been converted to farmland. Besides, excessive timber exploitation, grazing, and poaching have significantly contributed to such wanton deforestation.

\section{Discussion}

The type of forest cover classes identified: forest, plantation, farmland, grassland and bare land, in Ogbese forest reserve, is a characteristic of the forest ecosystem where the influence of anthropogenic activities has been on the increase. These cover features are quite similar to the ones obtained by [22] and [25] when they determined the land-use dynamics of a forest demonstration site in the southwestern part of Nigeria and an afromontane forest in northern Ethiopia, respectively.

The lowland reserve was much dominated by forest occupying about a half of the vegetation cover in the year 1998 while plantation accounted for about 13\% pulling the artificial and natural forest to about $61 \%$ of the entire forest reserve. By that year, agricultural activities have taken over about $20 \%$, while grassland and bare land together covered about $19 \%$. Anthropogenic activities have continued to aggravate in the reserve leading to the depletion of forest and unsustainable exploitation and reduction of the plantation to $8 \%$ in 2018 . While bare, grass and farmlands increased to $55 \%, 19 \%$, and $18 \%$ respectively.

The forestland in the reserve decreased until depletion at a rate of 1.72 $\mathrm{km}^{2} /$ year between 1998 and 2018, while the few areas of plantation left may continue to decrease at an annual rate of $0.18 \mathrm{~km}^{2}$, even more, if further depletion by encroachers like farmers and grazers are not forestalled. The decrease in the forest and plantation area was similar to [16] when they found that the natural forest in Ikere forest reserve was reduced to farmland and grassland. Likewise, [26] in his study on land-use change within Okomu and Gilli-Gilli forest re- 
serves, revealed that the deforestation resulting from farmland encroachment has increased by 37\% between 1984 and 2011 in Okomu forest reserve.

The total removal of the natural forest cover can be attributed to the government policy for revenue generation from the forest without replanting [27]. Once the government removes the trees from the forest, the land is exposed to agricultural activities. Also, it was observed that some certain factors engendered such exploitation and eventual depletion of plantations and forest, respectively. These factors can be linked to the usual anthropogenic activities which have been reportedly asserted to have caused a high rate of deforestation in most forests in the tropics, especially in Nigeria [4] [28] [29].

The level of disturbance, through the NDVI values obtained across the four epochs, reveals that the level of vegetation loss and eventual disturbance was relatively low in 1998 with an NDVI value of 0.25 but considerably increased by 2018 with a very low value of 0.13 (Figure 5). Even though such initially low value indicates that the factors of disturbance in the reserve have been in play before 1998, it could be deduced that the vegetation disturbance increased greatly afterwards, corroborated by the high rate of deforestation and vegetation loss experienced therein. Similarly, [26] recorded a reduction in the mean values of NDVI in Okomu and Gilli-Gilli forest reserves between 1984 and 2011, i.e. 0.4 to 0.31, while [18] obtained 0.39 in 2017 which decreased from 0.79 in 1972 across the land cover of the state that houses the understudied forest estate.

The aim to determine the drivers of deforestation in the reserve resulted in several possible options as revealed in Figure 6. Several factors drive this wanton rate of deforestation, most of which are; agriculture, timber extraction or excessive logging, poaching, uncontrolled fires, grazing, fuelwood collection, charcoal production and even unsustainable government policy [2] [4]. However, agriculture has been the major driver in most reserves, especially in southwestern states, owing to the richness of the soil, the relatively supporting climatic conditions, as well as the high distribution of people with farming as their primary source of livelihood [30] [31]. Meanwhile, through the ground-truthing done, it was observed that the largest part of the Ogbese forest reserve has been converted to farmlands containing several food crops like cassava, yam, maize, okra, rice and so on. This corroborates the assertion of [19] who in the 90s reported that more than 1000 hectares of the "western edge" of the reserve had been cleared and replaced by permanent agriculture, and that the establishment of monoculture plantations and encroachment by rural farmers for agricultural activities significantly culminated to degradation of substantial parts of most of the forest reserves in Southwestern Nigeria. As such, [32] and [33] reported two different neighbouring forests in Ondo state (Oluwa and Shasha forest reserves) to have been largely encroached by illegal farmers and thereby converted to farmland and scrubland. The rampant incidence of Fulani herdsmen in most Nigerian states has been recorded [34]. This must have also contributed to forest cover degradation even in Ogbese forest reserve as herdsmen have been reportedly sighted on several occasions for grazing their cattle. Conversely, urban ex- 
pansion has not really been a problem to the forest despite that it is close to the capital city-Ado Ekiti, although this may change in no time and pose challenge to the forest tree remnant or recruitment as the city is gradually developing [35].

\section{Conclusion}

There has been a substantial change in the vegetation cover of Ogbese Forest Reserve between 1998 and 2018 as a result of the increase in anthropogenic activities. Most significantly, the natural forest has given way to agricultural activities and decreased at the rate of $1.72 \mathrm{~km}^{2} /$ year until it was depleted by 2018 . However, the plantation forest initially increased in cover but later decreased at $-0.94 \mathrm{~km}^{2} /$ year, which could be depleted by 2025 . Forest cover started decreasing as a result of over-harvesting and consequent agricultural activities. This trend is relatively similar to many other forests in the country especially in the southwestern parts. The rate of encroachment would persist if the governments fail to take a sustainable step to forestall it and reforest the highly degraded reserves. Therefore, massive regeneration and reforestation programmes should be encouraged and effected on the forest reserves with functional policies. During and after the restoration process, there should be consistent monitoring of the forests, possibly with the use of higher resolution satellite, such as Spot, IKONOS to detect and prevent any subtle unpermitted encroachment and disturbance to the ecosystems. Any form of bias in this study findings may have resulted from either the imagery used or the classification technique adopted. Hence, further research could adopt better satellite imagery for more in-depth forest dynamics study in the reserve.

\section{Acknowledgements}

We would like to appreciate the personnel at the Department of Forestry, Ministry of Agriculture, Ekiti State, namely: Mr. Sanusi and Mr. Bakare, who were of assistance while collecting some data for this research work.

\section{Conflicts of Interest}

The authors declare that they have no conflict of interest.

\section{References}

[1] Lewis, S.L., Edwards, D.P. and Galbraith, D. (2015) Increasing Human Dominance of Tropical Forests. Science, 349, 827-832. https://doi.org/10.1126/science.aaa9932

[2] FAO (2016) State of the World's Forests 2016. Forests and Agriculture: Land-Use Challenges and Opportunities. Food and Agriculture Organization, Rome, 126.

[3] FAO (2005) State of the World's Forests 2005. Food and Agriculture Organization of the United Nations, Rome. https://fao.org/docrep/pdf/007/y5574e/y5574e00.pdf

[4] Fasona, M., Adeonipekun, P.A., Agboola, O.O., Akintuyi, A., Bello, A., Ogundipe, O.T., Soneye, A.S.O. and Omojola, A. (2018) Drivers of Deforestation and Land-Use Change in Southwest Nigeria. In: Leal Filho, W., Ed., Handbook of Cli- 
mate Change Resilience, Springer, Cham, 1-24.

https://doi.org/10.1007/978-3-319-71025-9_139-1

[5] Gbiri, I.A. and Adeoye, N.O. (2019) Analysis of Pattern and Extent of Deforestation in Akure Forest Reserve, Ondo State, Nigeria. Journal of Environmental Geography, 12, 1-11. https://doi.org/10.2478/jengeo-2019-0001

[6] Kassa, H., Dondeyne, S., Poesen, J., Frankl, A. and Nyssen, J. (2017) Transition from Forest-Based to Cereal-Based Agricultural Systems: A Review of the Drivers of Land Use Change and Degradation in Southwest Ethiopia. Land Degradation and Development, 28, 431-449. https://doi.org/10.1002/ldr.2575

[7] FAO (2016) Global Forest Resources Assessment 2015: How Are the World's Forests Changing? Second Edition, Food and Agriculture Organization of the United Nations, Rome, 54.

[8] Olayode, O.O. (2019) Spatio-Temporal Variations of Land-Cover Types in Osho Forest Reserve, Southwestern Nigeria. American Journal of Agriculture and Forestry, 7, 168-176. https://doi.org/10.11648/j.ajaf.20190705.12

[9] Duan, Q. and Tan, M. (2019) Spatial and Temporal Variations of Forest Cover in Developing Countries. Sustainability, 11, 1517. https://doi.org/10.3390/su11061517

[10] Yahya, N., Bekele, T., Gardi, O. and Blaser, J. (2020) Forest Cover Dynamics and Its Drivers of the Arba Gugu Forest in the Eastern Highlands of Ethiopia during 1986-2015. Remote Sensing Applications. Society and Environment, 20, Article ID: 100378. https://doi.org/10.1016/j.rsase.2020.100378

[11] Aspinall, R.J. (2008) Basic and Applied Land Use Science. In: Aspinall, R.J. and Hill, M.J., Eds., Land Use Change: Science, Policy and Management, CRC Press, Boca Raton, 3-15. https://doi.org/10.1201/9781420042979.pt1

[12] Woodcock, C.E., Loveland, T.R., Herold, M. and Bauer, M.E. (2020) Transitioning from Change Detection to Monitoring with Remote Sensing: A Paradigm Shift. Remote Sensing of Environment, 238, Article ID: 111558. https://doi.org/10.1016/j.rse.2019.111558

[13] Asokan, A. and Anitha, J. (2019) Change Detection Techniques for Remote Sensing Applications: A Survey. Earth Science Informatics, 12, 143-160. https://doi.org/10.1007/s12145-019-00380-5

[14] Beckline, M., Yujun, S., Yvette, B., John, A.B., Mor-Achankap, B., Saeed, S., Richard, T., Wose, J. and Paul, C. (2017) Perspectives of Remote Sensing and GIS Applications in Tropical Forest Management. American Journal of Agriculture and Forestry, 5, 33-39. https://doi.org/10.11648/j.ajaf.20170503.11

[15] Aderele, M.O., Bola, T.S. and Oke, D.O. (2020) Land Use/Land Cover Changes of Ago-Owu Forest Reserve, Osun State, Nigeria Using Remote Sensing Techniques. Open Journal of Forestry, 10, 401-411. https://doi.org/10.4236/ojf.2020.104025

[16] Alo, A.A. and Akindele, S.O. (2016) Deforestation Assessment in Ikere Forest Reserve, Nigeria Using Geographic Information System Technology. In: Adekunle, V.A.J., Oke, D.O. and Emehri, E.A., Eds., Proceedings of 5 th National Biennial Conference of the Forest and Forest Products Society on Forest Management and the Challenges of Environmental Sustainability, Delta State University, Abraka, 45-49.

[17] Alo, A.A., Akindele, S.O. and Onyekwelu, J.C. (2015) Development of Land Use Map of Eda Forest Reserve in Ekiti State, Nigeria. Journal of Applied Tropical Agriculture, 20, 19-23.

[18] Olorunfemi, I.E., Fasinmirin, J.T., Olufayo, A.A. and Komolafe, A.A. (2020) GIS 
and Remote Sensing-Based Analysis of the Impacts of Land Use/Land Cover Change (LULCC) on the Environmental Sustainability of Ekiti State, Southwestern Nigeria. Environment, Development and Sustainability, 22, 661-692. https://doi.org/10.1007/s10668-018-0214-Z

[19] Ola-Adams, B.A. (1981) Strategies for Conservation and Utilization of Forest Genetic Resources in Nigeria. The Nigerian Journal of Forestry, 2, 32-39.

[20] Faboya, I.O., Adebola, S.I. and Awotoye, O.O. (2005) Assessment of Decomposition Rate and Soil Nutrient Status under Different Woody Species Combination in a Tree Plantation. Agriculture, Forestry and Fisheries, 4, 46-54. https://doi.org/10.11648/j.aff.20150402.14

[21] Oke, D.O. and Olatilu, A. (2011) Carbon Storage in Agroecosystems: A Case Study of the Cocoa Based Agroforestry in Ogbese Forest Reserve, Ekiti State, Nigeria. Journal of Environmental Protection, 2, 1069-1075.

https://doi.org/10.4236/jep.2011.28123

[22] Ilelakinwa, G.A. and Alo, A.A. (2018) Land Use and Land Cover Dynamics of Faculty of Agriculture and Forestry Practical Demonstration Site, Ileogbo, Osun State, Nigeria. Proceedings of 6 th Biennial National Conference of the Forests and Forest Products Society, Usman dan fodio University, Sokoto State, 23-27 April 2018, 242-250.

[23] Agbor, C.F., Oluwole, J.P., Ogoliegbune, M.O., Aigbokhan, O.J. and Justina, M. (2020) Comparative Analysis of Non-Linear Artificial Neural Networks and Maximum Likelihood Algorithms in Forest Cover Studies. Journal of Research in Forestry, Wildlife and Environment, 12, 299-310. https://www.ajol.info/index.php/jrfwe/article/view/198397/187073

[24] Anderson, J.R. (1976) A Land Use and Land Cover Classification System for Use with Remote Sensor Data. US Government Printing Office, Washington DC, 964. https://doi.org/10.3133/pp964

[25] Solomon, N., Segnon, A.C. and Birhane, E. (2019) Ecosystem Service Values Changes in Response to Land-Use/Land-Cover Dynamics in Dry Afromontane Forest in Northern Ethiopia. International Journal of Environmental Research and Public Health, 16, 4653. https://doi.org/10.3390/ijerph16234653

[26] Alayande, A. (2016) Landuse Change within Okomu and Gilli-Gilli Forest Reserves, Southwestern Nigeria: Its Climatic and Societal Implications. Tropical Ecology, 57, 193-203.

[27] Alo, A.A., Akindele, S.O. and Onyekwelu, J.C. (2014) Development of Information System for Forest Resources in Ekiti State, Nigeria. International Journal of Research in Agricultural Sciences, 1, 373-378.

[28] Ngwira, S. and Watanabe, T. (2019) An Analysis of the Causes of Deforestation in Malawi: A Case of Mwazisi. Land, 8, 48. https://doi.org/10.3390/land8030048

[29] Hosonuma, N., Herold, M., de Sy, V., de Fries, R.S., Brockhaus, M., Verchot, L., Angelsen, A. and Romijn, E. (2012) An Assessment of Deforestation and Forest Degradation Drivers in Developing Countries. Environmental Research Letter, 7, Article ID: 044009. https://doi.org/10.1088/1748-9326/7/4/044009

[30] Fasona, M.J., Akintuyi, A.O., Adeonipekun, P.A., Akoso, T.M., Udofia, S.K., Agboola, O.O., Ogunsanwo, G.E., Ariori, A.N., Omojola, A.S., Soneye, A.S. and Ogundipe, O.T. (2020) Recent Trends in Land-Use and Cover Change and Deforestation in South-West Nigeria. GeoJournal. https://doi.org/10.1007/s10708-020-10318-w

[31] Adekugbe, O.A., Oyerinde, O.V., Oluwajuwon, T.V., Abisoye, T.R. and Atanda, T.A. (2020) Socio-Economic Characteristics and Level of Awareness and Perception 
on Reducing Emissions from Deforestation and Forest Degradation Programme (REDD+) by Rural Communities in Akure Forest Reserve, Nigeria. Journal of Applied Sciences and Environmental Management, 24, 1909-1915.

[32] Orimoogunje, O.O.I., Ekanade, O. and Adesina, F.A. (2009) Land Use Changes and Forest Reserve Management in a Changing Environment: South-Western Nigeria Experience. Journal of Geography and Regional Planning, 2, 283-290.

[33] Alo, A.A., Adetola, A.A. and Agbor, C.F. (2020) Modelling Forest Cover Dynamics in Shasha Forest Reserve, Osun State, Nigeria. Journal of Agriculture and Environment, 16, 129-142.

[34] Ducrotoy, M.J., Majekodunmi, A.O., Shaw, A.P., Bagulo, H., Bertu, W.J., Gusi, A.M., Ocholi, R. and Welburn, S.C. (2018) Patterns of Passage into Protected Areas: Drivers and Outcomes of Fulani Immigration, Settlement and Integration into the Kachia Grazing Reserve, Northwest Nigeria. Pastoralism, 8, Article No. 1. https://doi.org/10.1186/s13570-017-0105-1

[35] Oriye, O. (2013) Urban Expansion and Urban Land Use in Ado Ekiti, Nigeria. American Journal of Research Communication, 1, 128-139. 